\title{
Examination of equine glandular stomach lesions for bacteria, including Helicobacter spp by fluorescence in situ hybridisation
}

\author{
Louise Husted ${ }^{1}$, Tim K Jensen², Susanne N Olsen ${ }^{1}$, Lars Mølbak ${ }^{2 *}$
}

\begin{abstract}
Background: The equine glandular stomach is commonly affected by erosion and ulceration. The aim of this study was to assess whether bacteria, including Helicobacter, could be involved in the aetiology of gastric glandular lesions seen in horses.

Results: Stomach lesions, as well as normal appearing mucosa were obtained from horses slaughtered for human consumption. All samples were tested for urease activity using the Pyloritek $k^{\oplus}$ assay, while mucosal bacterial content was evaluated using Fluorescence In Situ Hybridisation. In selected sub samples, bacteria characterisation was pursued further by cloning and sequencing. Mucosal lesions were found in 36/63 stomachs and included hyperplastic rugae, polypoid structures and focal erosions. None of the samples were tested positive for urease activity or for FISH using the Helicobacter genus specific probe. In samples of lesions, as well as normal samples, clones with $99 \%$ similarities to Lactobacillus salivarius and Sarcina ventriculi were found. Escherichia like bacterium clones and Enterococcus clones were demonstrated in one focal erosion. Based on a phylogenetic tree these clones had 100\% similarity to Escherichia fergusonii and Enterococcus faecium. The Enterococcus were found colonising the mucosal surface, while E. fergusonii organisms were also demonstrated intraepithelial.

Conclusion: Gastric Helicobacter spp. could not be verified as being involved in lesions of the glandular stomach of the horse. Since E. fergusonii has been described as an emerging pathogen in both humans and animals, the finding of this bacterium in gastric erosion warrants further clarification to whether gastric infection with this type bacterium is important for horses.
\end{abstract}

\section{Background}

In horses, lesions of the non-glandular part of the stomach are highly prevalent and seem to be caused by excessive acid exposure [1], but little has been described regarding lesions in the glandular part. Lesions located in the glandular region were demonstrated in $58 \%$ of 162 hospitalized horses [2] and in $47 \%$ of 345 racehorses [3] and while the cause of these have not received much attention, acid exposure does not seem to be the primary factor, as no correlation between lesions of the two regions of the stomach has been found [3].

Gastric bacteria as the cause for glandular stomach lesions have been suggested for many animal species and in humans these constitute a major verified risk

\footnotetext{
* Correspondence: larmo@vet.dtu.dk

2Danish Veterinary Institute, Technical University of Denmark, Bülowsvej 27,
} 1790 Copenhagen V, Denmark factor. Of the gastric organisms found, Helicobacter pylori has been described the most due to its pathogenic potential of inducing chronic gastritis, ulcers, adenocarcinomas and mucosa associated lymphoid tissue (MALT) lymphoma in humans [4-6]. Bacteria of this genus have also been found in gastric tissue samples from animals including dogs, pigs, sheep and cattle [7-10].

In the horse, contradictory evidence exits as to whether bacteria that specifically can cause gastric lesions occur. A few studies have indicated that gastric Helicobacter spp. are present in normal appearing mucosa by using PCR and immunochemistry $[11,12]$, while others have found no evidence of a connection between the presence of lesions and bacteria [13]. As gastric bacterial species have been confirmed or suggested as part of the pathogenesis of certain types of

\section{Biomed Central}


gastric pathology in humans and other animal species, the aim of this study was to assess if bacteria could be involved in the pathology observed in the equine glandular stomach. A main focus was to provide more evidence regarding the presence and localisation of bacteria in general at the mucosa level of the equine glandular stomach. Special emphasis was put on obtaining information regarding the presence and involvement of any Helicobacter species in the mucosal lesions. The Fluorescence In situ hybridisation (FISH) technique was used for this purpose which allows the use of rRNA-targeted probes for both the total bacterial population and defined genus/species. This approach permits the determination of bacterial morphology, abundance, location in the tissues, and even indications on growth rates and physiological activities [14].

\section{Results}

Gross glandular lesions were seen in 36 of the 63 stomachs examined (57.1\%). The majority of lesions were seen in the antrum region (91.7\%). In six stomachs, lesions were additionally or exclusively seen in the cardia or corpus region. No lesions were found in the duodenum.

The lesions were classified in three groups as: Polypous ( 2 stomachs with polypoid masses located in both the cardia and the antrum with sizes between 1 and 5 centimetres in diameter), ii: Hyperplastic rugae lesions (13 stomachs) or iii: Hyperaemic, erosive or ulcerative lesions, which were seen in 21 stomachs.

The hyperplastic rugae were all seen in the antrum and ranged from having intense hyperemia with exudate to rugae with normally appearing mucosal surface. Gross thickening of the antrum rugae was caused primarily by hyperplasia of the gastric foveolae compared to the respective normal samples. The remaining lesions were all found to be small solitary lesions of no more than approximately $1 \times 2 \mathrm{~cm}$ in size. Focal areas of erosive gastritis was the most common findings of these type lesions and characterised as sloughing of the superficial cells of the luminal epithelium with a concurrent fibrinopurulent exudate, luminal cellular debris and a predominantly mononuclear cell infiltrate of the lamina propria. Deeper erosions found in 9 stomachs eroded both the region of the gastric pits and parts of the glands, which was observed with gastritis only of the immediate tissues. One true ulcer was found extending the full thickness of the lamina propria, exposing the lamina muscularis to the lumen. A maximum of two lesions were found in each of these stomachs.

\section{Helicobacter and Urease activity test}

Using the genus Helicobacter specific probe no positive signals were found in any of the 79 tissue samples (36 paired samples and 7 controls). In agreement with these results of the $\mathrm{FISH}$, none of the samples tested positive for urease activity either. Internal controls of all urease tests were found positive as indication of a functional test kit.

\section{Bacteria in general}

In general, only few bacteria were observed related to the mucosal surface in both the injured as well as in the healthy stomach samples. Overall, four morphological different types of bacterial cells could be visualized with the Eubacteria probe: 1$)$ small, short $(0.2-0.5 \mu \mathrm{m})$ coccoid rods, 2) distinct rods $(1 \times 3 \mu \mathrm{m}), 3)$ long chained rods (up to $60 \mu \mathrm{m})$ or 4 ) large $(2-3 \mu \mathrm{m}$ diameter) coccoid bacteria clearly dividing in pairs. Typically when present, bacteria were observed in clusters associated with feed particles or located close to the mucosal surface

Evidence of bacterial gastritis was found in one stomach lesion grossly characterised as a solitary erosion, $1 \times 2 \mathrm{~cm}$ in size, the centre being hyperaemic and surrounded by a proliferative epithelial rim (Fig. 1). Microscopically, focal erosion of the mucosa with oozing of erythrocytes and leukocytes, mainly of neutrophilic origin, was seen. The exudates were additionally seen in the gastric pits. A cellular inflammatory reaction with mononuclear cells was seen extending as deep as into the lamina muscularis. The surface of the inflamed mucosa and the gastric pits were found heavily colonised by coccoid to short rods applying the probe for general bacteria (Fig. 2). The short rods were especially

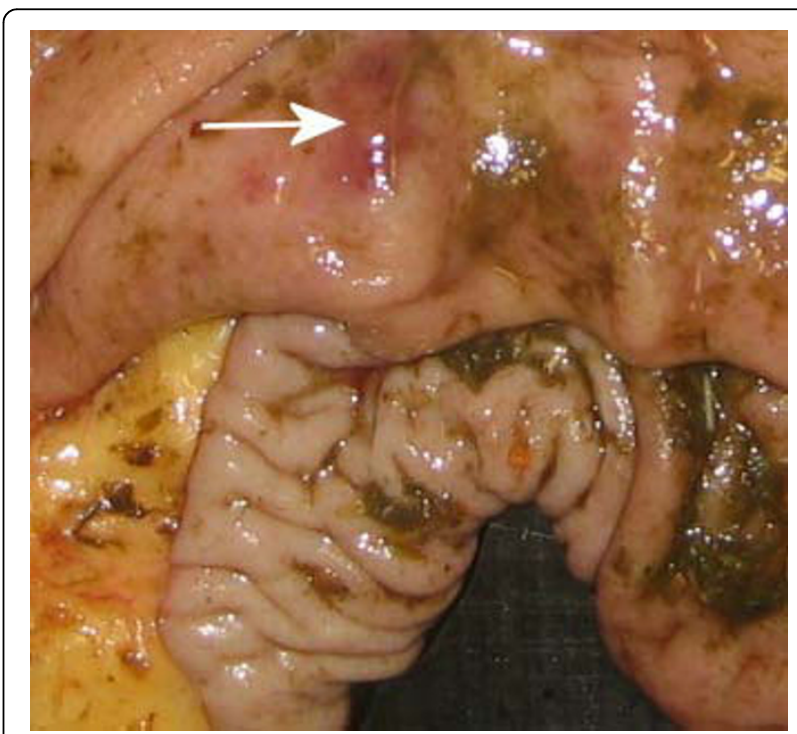

Figure 1 Focal erosive lesion (white arrow) demonstrating bacterial gastritis at histological evaluation. Lesion was approximately $2 \times 2 \mathrm{~cm}$ and located in the antrum near the pyloric entrance. 


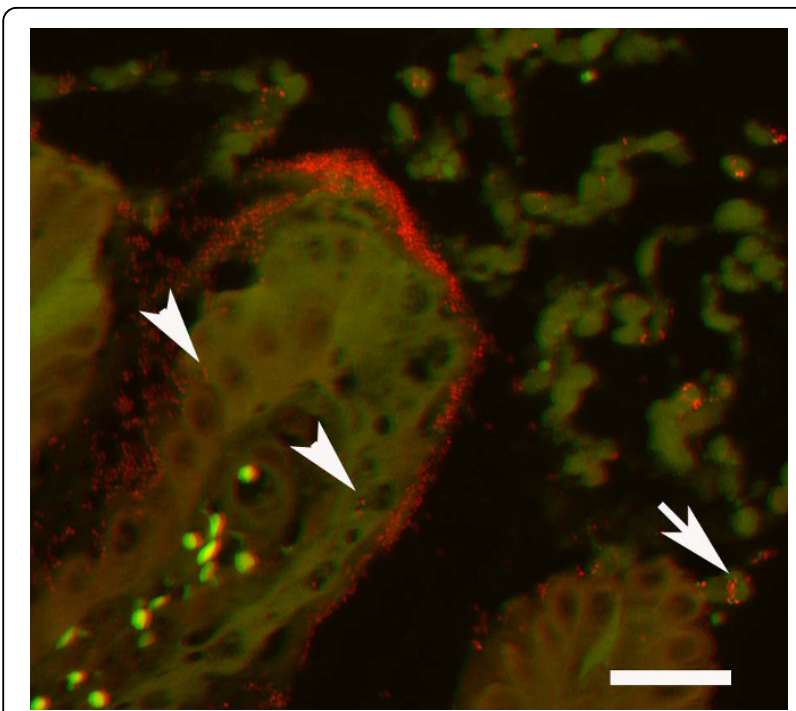

Figure 2 Gastric mucosa with erosive gastritis associated with bacteria. The mucosal surface and adjacent cellular debris is severely colonised by bacteria (red). A few bacteria are seen intracellular in the intact epithelium (arrowhead) as well as within degenerated and necrotic epithelial cells (arrow). In addition, bacteria are found within granulocytes. Fluorescent in situ hybridisation with the probe targeting Bacteria, filter set 43 , bar $=$ $25 \mu \mathrm{m}$.

observed infiltrating the erosion. They were also observed intracellular in epithelial cells, as well as within neutrophilic granulocytes. The bacterial colonisation of the stomach was restricted to the lesion as no bacteria were seen in the corresponding healthy mucosa sample.

\section{Cloning and sequencing}

Based on the morphology and intensity of bacteria demonstrated using FISH, subsamples of the $\mathrm{C} / \mathrm{c}$ samples were selected for cloning and sequencing of representing samples including the one with bacterial gastritis.

Of the chosen subsamples of stomachs demonstrating various bacteria morphologies, two different types of clones were found in normal appearing mucosa samples (c samples), one clone had 99\% similarity to Lactobacillus salivarius JCM 1231 (AB370881) and the other type of clones had 99\% similarity to Sarcina ventriculi DSM 316 (X76650).

From the lesions (C samples), clones were also found with 99\% similarity to Lactobacillus salivarius JCM 1231 (AF182725). From the mucosa with bacterial gastritis, four of ten clones matched 100\% Enterococcus faecium, while the remaining six clones (obtained sequence deposited at GenBank with the accession no. GQ423062) belonged to an Escherichia like bacterium. A phylogenetic tree was constructed with the six Escherichia like clones from the lesion and all had 100\%

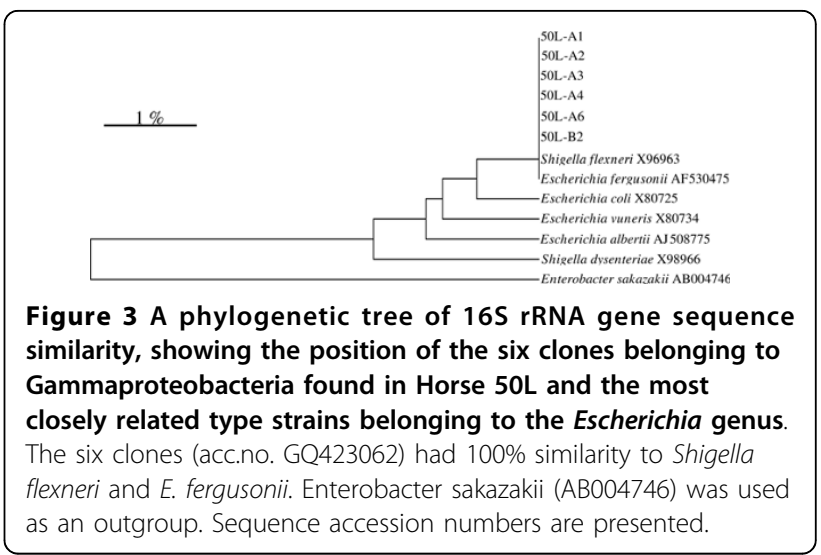

similarity to the type strains of both E. fergusonii and Shigella flexneri (fig 3). Applying a gamma proteobacteria specific probe the short rods infiltrating the epithelium, as well as found intracellular within neutrophilic granulocytes, were verified as the Escherichia like bacterium while Enterococcus faecium organisms were identified colonising the epithelial surface by the Enterococcus specific probe (Fig 4 and 5).

\section{Discussion}

Previous studies involving the equine stomach have e.g. used PCR targeting the 16S rRNA gene of especially Helicobacter spp. [12]. The disadvantages using PCR are that the amount and location of the bacteria is not

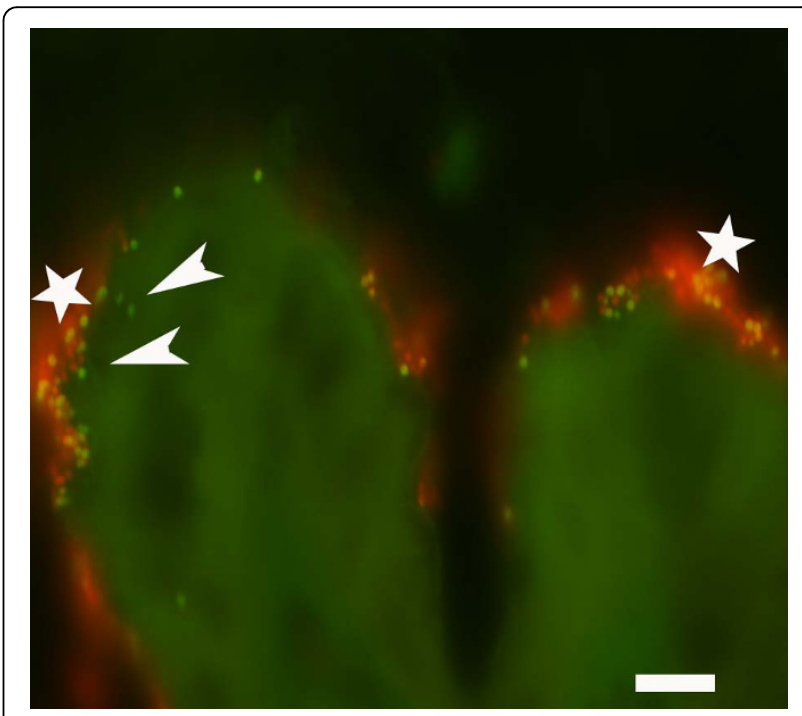

Figure 4 Gastric mucosa of horse $50 \mathrm{~L}$ with erosive gastritis associated with bacteria. Applying a fluorescein labelled probe for Gammaproteobacteria and a Cy3 labelled probe for Enterococcus, an E. coli like organism (green) (arrowhead) was found intracellular within epithelial cells and on the epithelial surface whereas $E$. faecium (red) ('white star'(only colonised the epithelial surface. Filter set $43 / 38$, bar $=10 \mu \mathrm{m}$. 


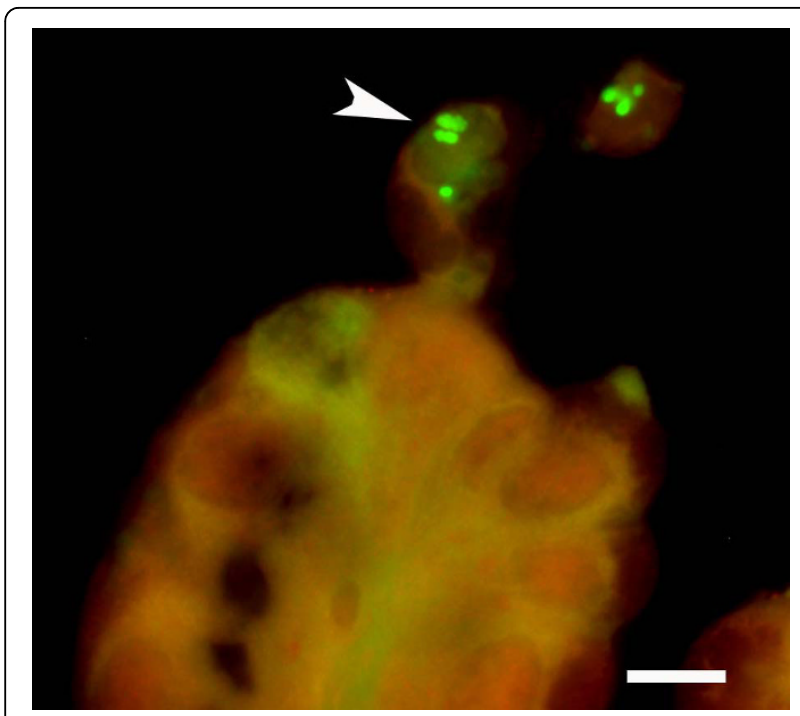

Figure 5 Gastric mucosa of horse $50 \mathrm{~L}$ with erosive gastritis associated with bacteria. High magnification demonstrating E. coli like rods (green) within extruded epithelial cells. Fluorescent in situ hybridisation with the probe targeting Gammaproteobacteria, filter set 38 , bar $=10 \mu \mathrm{m}$.

known and it is uncertain whether the bacteria are alive or even if the DNA is naked. Hence, it was decided that using the FISH technique would provide better and more information of the bacteria found in the glandular stomach of the horse, as these issues are overcome with this technique. This technique has been used previously to describe the spatial distribution of Helicobacter spp. in the gastrointestinal tract of dogs and in the stomach of healthy horses to demonstrate the microbiota of the normal appearing squamous and glandular mucosa $[15,16]$. To the best of our knowledge this is the first study using FISH to examine lesions of the glandular stomach.

In the present study one case of gastritis associated with bacterial colonisation was revealed. Especially the distribution of bacteria suggested a connection with the pathology observed. The amount of bacteria was markedly increased around the lesion and were tightly adhered to the epithelial cells, with the bacteria extending into the crypts and located intracellular. The cloning showed that it was a double infection with Enterococcus faecium and an Escherichia like bacterium, but it was subsequently verified using the in situ hybridisation with a gamma proteobacteria probe that it was only the Escherichia like bacterium which infiltrated the superficial ulcerations and were found intracellular in epithelial cells and within neutrophilic granulocytes. Enterobacterial infection in the intestine is a common phenomenon, but it is rare to find these infections in the stomach and it has never before been reported in adult horses. This result is very intriguing but further studies need to clarify how common this phenomenon is in horses. Also, whether this type of infection is of primary or secondary origin would need further clarification. The Escherichia like clones all had $100 \% 16 \mathrm{~S}$ rRNA gene similarity to both E. fergusonii and Shigella flexneri. Thus, in this study, it can not be precised experimentally which of these two organisms that were present in this glandular lesion. However, humans have been reported to be the only natural host for Shigella [17] whereas E. fergusonii has been associated with a wide variety of intestinal and extra-intestinal infections in both humans and animals including horses[18,19]. It is therefore most likely that the Escherichia like bacterium found in this study belongs to E. fergusonii. Studies have reported E. fergusonii as an emerging pathogen and associated with especially bacteraemia and wound infection but its precise role in infections in both humans and animals still has to be elucidated [20].

\section{Microbiology in the samples}

The environment in the glandular stomach is generally very hostile toward microbes [21]. It is well established that, unlike humans and dogs that are meal feeders, horses are continuous acid producers, probably due to a continuous feeding pattern [22,23]. The $\mathrm{pH}$ in the ventral part of the equine stomach is stable at around $\mathrm{pH}$ 1-3 throughout the 24 hour period [24], consequently the relative low diversity of bacteria observed in mucosal samples in this study was not unexpected.

The characteristic morphological phenotype of large cocci growing in regular tetrads was established to be a clone with a $99 \%$ similarity to Sarcina ventriculi. This organism is known to be able to grow in stomach contents and has the characteristic tetrade structure when grown from $\mathrm{pH} 1-\mathrm{pH} 3$ [25]. In the current study, the finding of these organisms could not be established to be part of any specific pathology, as they were found in low numbers in the paired samples (i.e. lesion and normal), as well as in the control samples. Sarcina-like bacteria have been found in a variety of species, where they have been supposed to cause abomasal bloat, haemorrhage and ulcers in lambs and goat kids [26,27] and a possible link to gastric dilatation in both dogs and horses has also been suggested [28]. No evidence of gas accumulations was observed macroscopically in any of these horses and hence it does not seem that the presence of Sarcina ventriculi contributed to the pathology observed in these horses.

It was not surprising that Lactobacillus (Lactobacillus salivarius) was found in the studied tissues and it has previously been reported that several Lactobacillus spp., including $L$. salivarius, are present in healthy horses $[16,29]$. The proximal equine stomach functions as storage 
for feed, as well as a compartment for intragastric fermentation. The ecosystem in this region consists of both anaerobic and lactate-utilizing bacteria in large numbers, which are responsible for the increase in volatile fatty acids upon fermentation of carbohydrates [30]. Especially Lactobacilli were found adhering to the epithelium in the proximal part of the equine stomach [31] and these bacteria will likely pass to the glandular stomach as part of the normal turn-over. We have only examined subsamples and more bacterial taxa will be found in the healthy part of the glandular stomach if a more comprehensive microbiota community study was done.

\section{Validity of the findings of Helicobacter}

None of the tissue samples from the antrum region demonstrated positive signals from the Helicobacter spp. probe in this study and no spiral shaped bacteria were noted using the FISH technique either. In a recent study from Venezuela, spiral shaped bacteria were reported in biopsies from the cardiac region of the equine stomach stained with the Warthin-Starry stain [12]. Helicobacter spp. known to be able to colonize the stomach produce large amounts of cytoplasmic urease[32] The rapid urease test used in this investigation, Pyloritek ${ }^{\oplus}$, detects the urease activity of the tissue sample by the production of ammonia when urea is present. It is extensively used in human practice to detect gastritis caused by Helicobacter spp. The positive and negative predictive values were between 98.1-100\% and 95.8-100\%, respectively in a study testing human patients before and after eradication of the bacterium [33]. In this study, no positive tests were found, indicating that the biopsies in the present study contained no bacteria with the ability to produce urease.

\section{Conclusions}

Gastric Helicobacter spp. was not found and could not be linked to the stomach lesions of the 36 horses analyzed in this study. The pathology found in this study included polypoid structures, hyperplastic rugae and small erosions, but bacterial involvement was found in only one case of an erosion. In this lesion, an Escherichia-like clone, most likely E. fergusonii, was found intracellular. Whether this was a primary or secondary infection could not be concluded. Very limited amounts of bacteria in general were found in the equine glandular region as expected. Thus, detection of a moderate to high amounts of any bacteria at the glandular mucosa level, as well as in the crypts should be cause for concern as this does not seem to be a normal finding in the equine glandular stomach. Further studies involving bacteria and the relation to gastric lesions of horses with confirmed clinical signs are warranted, as these horses were not included in the current study.

\section{Methods}

\section{Horses and study design}

The study was done as a cross-sectional study of stomachs from a population of 63 abattoir horses in Denmark. Horses were approved by the Veterinary Officer as healthy for slaughter. Horses were stunned with a captive bolt and exsanguinated. The stomach, including $5-10 \mathrm{~cm}$ of the distal esophagus and $10 \mathrm{~cm}$ of the proximal duodenum, was removed immediately after evisceration and opened along the greater curvature. Ingesta were removed and if necessary, the mucosa was gently rinsed with a minimum of tap water before inspection. Only stomachs with gross lesions in the glandular mucosa were included, as well as seven control stomachs with no gross evidence of gastric lesions.

Glandular lesions were defined as the mucosa having an abnormal macroscopic appearance i.e. hyperaemic, increased thickness, erosions or ulcers. The anatomical positions of the lesions were noted as: The cardia, corpus or antrum region (Fig. 6).

\section{Sampling procedure}

From each stomach with glandular lesions, three tissue samples where obtained of the largest lesion (A, B, C) as well as three paired normal appearing tissue samples (a, $b, c)$ from the same anatomical region, but at least at least $5 \mathrm{~cm}$ away. A/a: a small, biopsy size $(0,5 \times 0,5 \mathrm{~cm})$ mucosa sample was obtained for immediate urease testing with the Pyloritek ${ }^{\circledR}$ assay according to the manufactures instructions. Tests were read after a 60 minute

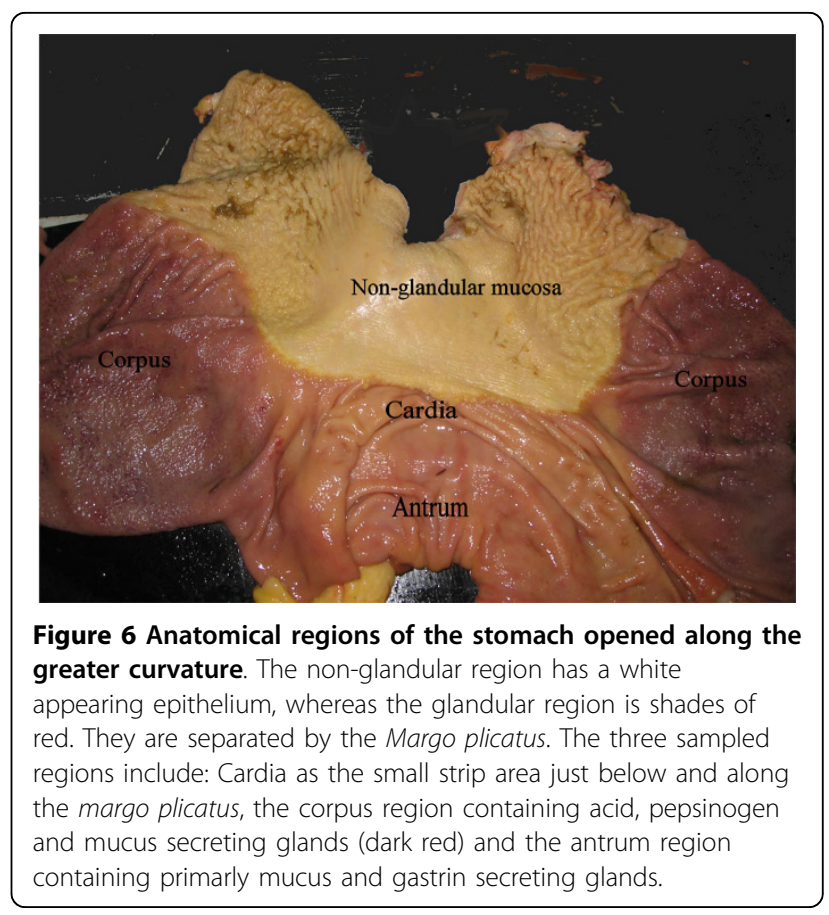


standard time and results noted as positive or negative. Samples B/b: a $3 \times 3 \mathrm{~cm}$ full thickness tissue sample including mucosa and submucosa were obtained for FISH and fixed in $10 \%$ buffered formalin. After 24 hours fixation the samples were transferred to $70 \%$ ethanol, paraffin-embedded, sectioned at $3 \mu \mathrm{m}$ and mounted on SuperFrost/plus slides (Menzel-Gläser, Braunschweig Germany).

Samples C/c: a third pair of tissue samples for cloning and sequencing was obtained and snap frozen using dry ice (If lesion size allowed it).

From the seven control stomachs with no macroscopic gastric lesions, samples $\mathrm{a}, \mathrm{b}$ and $\mathrm{c}$ were taken from the normal appearing mucosa of the antrum. Three of these horses were additionally sampled in the cardia, corpus and duodenum as well.

The sampling procedures took place from August to October 2007. Historical data regarding previous health of the horses could not be obtained.

\section{Fluorescent In Situ Hybridisation for bacteria}

For microbial detection, the tissue sections were hybridized simultaneously with two 16S rRNA probes labelled with different fluorophores. The oligonucleotide probe S-D-BACT-0338-a-A-18 targeting Bacteria (5'GCTGCCTCCCGTAGGAGT3') [34] was 5' labeled with the fluorescein isothiocyanate and with isothiocyanate derivative Cy3. The oligonucleotide probe HEL717 targeting the Helicobacter genus (5'AGGTCGCCTTCGCAATGAGTA3') [35] was 5' labeled with isothiocyanate derivative $\mathrm{Cy} 3$. To verify the cloning results a third and fourth probe, L-C-gProt-1027-a-A-17 (5'GCCTTCCCACATCGTTT3') targeting 23S rRNA of Gammaproteobacteria was 5' labeled with the fluorescein isothiocyanate and probe S-G-Enteroco-184 (5'CAAATCAAAACCATGCGG3') was Cy3 labeled targeting 16S rRNA of Enterococcus spp[36]. All probes were synthesised at DNA Technology, Aarhus, Denmark. The slides were deparaffinized in xylene and transferred to $100 \%$ alcohol for $30 \mathrm{~min}$ before hybridisation. The hybridisation was carried out at $45^{\circ} \mathrm{C}$ with $40 \mathrm{ml}$ of hybridisation buffer (100 mM Tris [pH 7.2], $0.9 \mathrm{M} \mathrm{NaCl}, 0.1 \%$ sodium dodecyl sulfate) and $200 \mathrm{ng}$ of each probe for 16 hours in a Sequenza Slide Rack (Thermo Shandon, Cheshire, UK). The samples were then washed three times in prewarmed $\left(45^{\circ} \mathrm{C}\right)$ hybridisation buffer for $15 \mathrm{~min}$ and subsequently three times in prewarmed $\left(45^{\circ} \mathrm{C}\right)$ washing solution (100 mM Tris [pH 7.2], 0.9 M NaCl). The samples were rinsed in water, air dried and mounted in Vectashield (Vector Laboratories Inc., Burlingame, CA, USA) for epifluorescence microscopy. An Axioimager M1 epifluorescence microscope equipped for epifluorescence with a 100-W HBO lamp and filter sets 43 and 38 were used to visualize $\mathrm{Cy} 3$ and fluorescein, respectively.
Images were obtained using an AxioCam MRm version 3 FireWiremonocrome camera and the software AxioVision version 4.5 (Carl Zeiss, Oberkochen, Germany).

Evaluation of the epifluorescence microscopy was performed by description of the subjective amount, morphologic appearance and location of fluorescing cells apparent in each tissue sample. In addition, all tissue sections were stained by $H \& E$ and evaluated histopathologically.

\section{$16 \mathrm{~S}$ rDNA amplification and cloning}

After the detection of bacteria using FISH, sub samples from horses demonstrating bacteria of various morphologies were chosen for $16 \mathrm{~S}$ rRNA gene cloning. The DNA was isolated from 4 tissue samples by using the Easy-DNA kit (Invitrogen, Tåstrup, Denmark) according to the manufacturer's instructions. The $16 \mathrm{~S}$ rRNA gene was amplified using primers S-D-Bact-0008-a-S-20 (5'AGAGTTTGATCMTGGCTCAG-3') [37] and S-"*Univ1492-a-A-19 (5'-GGTTACCTTGTTACGACTT-3') [38]. PCR cycling consisted of an initial denaturation at $94^{\circ} \mathrm{C}$ for $6 \mathrm{~min}$; followed by 30 cycles of denaturation at $94^{\circ} \mathrm{C}$ for $30 \mathrm{~s}$, annealing at $55^{\circ} \mathrm{C}$ for $45 \mathrm{~s}$ and extension at $72^{\circ} \mathrm{C}$ for $2 \mathrm{~min}$; and a final extension at $72^{\circ} \mathrm{C}$ for $3 \mathrm{~min}$. Amplified DNA was verified by electrophoresis on agarose gels. The PCR products were purified using the QIAquick PCR purification kit columns (Qiagen $\mathrm{GmbH}$, Hilden, Germany). To create blunt-ended DNA the following was mixed in a $0.5-\mathrm{ml}$ microcentrifuge tube, $4 \mu \mathrm{l}$ of $5 \times$ T4 DNA polymerase buffer, $14.7 \mu \mathrm{l}$ of purified PCR product $0.8 \mu \mathrm{l}$ of dNTP $\left(2.5 \mathrm{mmol} \mathrm{l}^{-1}\right.$ each $)$ and $0.5 \mu \mathrm{l}(1.2 \mathrm{U})$ of T4 DNA polymerase (Invitrogen) and incubated at $12^{\circ} \mathrm{C}$ for $15 \mathrm{~min}$. The T4 DNA polymerase was heat-inactivated, and the blunt-ended DNA was purified using the QIAquick PCR purification kit columns (Qiagen $\mathrm{GmbH}$ ) and eluted in a final volume of $10 \mu \mathrm{l}$ of double-distilled water. Following the manufacturer's descriptions the cloning was performed by using a Zero blunt TOPO cloning kit (Invitrogen). Ten colonies from each cloning were picked and sequenced on an automatic sequence analyser (ABI PRISM 373 DNA Sequencer; PE Biosystems, Foster City, CA, USA) by using the two standard vector primers ( $\mathrm{T} 3$ and $\mathrm{T} 7$ ) included in the kit. The sequence was assembled in Bionumerics version 4.0 (Applied Math, Sint-MartensLatem, Belgium) and checked for chimeras both by blasting the individual sequences in GenBank http:// www.ncbi.nlm.nih.gov and by the software Pintail version 1.1 http://www.cardiff.ac.uk/biosi/research/biosoft/. The phylogenetic analysis of the clones belonging to the Escherichia genus was done by downloading 16S rRNA gene sequences longer than 1,200 bp from the RDP v.9 database of the Escherichia type strains http://rdp.cme. msu.edu. The sequences were trimmed to the same 
length of $1327 \mathrm{bp}$ and aligned pairwise (UPGMA) followed by a global sequence alignment. A final phylogenetic tree was constructed by using the WARD algorithm where Enterobacter sakazakii (AB004746) was used as outgroup.

\section{Acknowledgements}

The authors wish to thank Hanne H. Møller, Katja Kristensen and Johanna Z Amenuvor for technical assistance in the laboratories. Also thanks to Stina Vesterholm for helping collecting tissues. This work was supported by Kongeriget Danmark's Horseinsurance g/s and Intervet Denmark. Sponsors had no involvement in the practical part or conclusions of this study.

\section{Author details}

'Department of Large Animal Sciences, Faculty of Life Sciences, University of Copenhagen, Hoejbakkegaard Allé 5, 2630 Taastrup, Denmark. ²Danish Veterinary Institute, Technical University of Denmark, Bülowsvej 27, 1790 Copenhagen V, Denmark.

\section{Authors' contributions}

LH conceived and designed the study, collected and prepared the tissues, performed Fluorescence In Situ Hybridisation and drafted the manuscript. TKJ and LM assisted in designing the study, making microscopic images, performed the cloning and sequencing and drafted the manuscript. SNO participated in designing the study and helped draft the manuscript. All authors read and approved the final manuscript.

Received: 31 July 2009 Accepted: 19 March 2010

Published: 19 March 2010

\section{References}

1. Lorenzo-Figueras M, Merritt AM: Effects of exercise on gastric volume and $\mathrm{pH}$ in the proximal portion of the stomach of horses. Am J Vet Res 2002, 63:1481-1487.

2. Murray MJ, Nout YS, Ward DL: Endoscopic findings of the gastric antrum and pylorus in horses: 162 cases (1996-2000). J Vet Intern Med 2001, 15:401-406.

3. Begg LM, O'Sullivan CB: The prevalence and distribution of gastric ulceration in 345 racehorses. Aust Vet J 2003, 81:199-201.

4. De Groote D, Van Doorn L, Van den BK, Vandamme P, Vieth M, Stolte M, Debongnie JC, Burette A, Haesebrouck F, Ducatelle R: Detection of nonpylori Helicobacter species in "Helicobacter heilmannii"-infected humans. Helicobacter 2005, 10:398-406.

5. Heilmann KL, Borchard F: Gastritis due to spiral shaped bacteria other than Helicobacter pylori: clinical, histological, and ultrastructural findings. Gut 1991, 32:137-140.

6. Peter S, Beglinger C: Helicobacter pylori and gastric cancer: the causal relationship. Digestion 2007, 75:25-35.

7. Cattoli G, van Vugt R, Zanoni RG, Sanguinetti V, Chiocchetti R, Gualtieri M, Vandenbroucke-Grauls CMJE, Gaastra W, Kusters JG: Occurrence and characterization of gastric Helicobacter spp. in naturally infected dogs. Vet Microbiol 1999, 70:239-250.

8. De Groote D, van Doorn L, Ducatelle R, Verschuuren A, Haesebrouck F, Quint WGV, Jalava K, Vandamme P: 'Candidatus Helicobacter suis', a gastric helicobacter from pigs, and its phylogenetic relatedness to other gastrospirilla. Int I Syst Evol Microbiol 1999, 49:1769-1777.

9. De Groote D, Van Doorn LJ, Ducatelle R, Verschuuren A, Tilmant K, Quint WGV, Haesebrouck F, Vandamme P: Phylogenetic characterization of 'Candidatus Helicobacter bovis', a new gastric helicobacter in cattle. Int J Syst Evol Microbiol 1999, 49:1707-1715.

10. Dore MP, Sepulveda AR, El-Zimaity H, Yamaoka Y, Osato MS, Mototsugu K Nieddu AM, Realdi G, Graham DY: Isolation of Helicobacter pylori from sheep-implications for transmission to humans. Am J Gastroenterol 2001, 96:1396-1401.

11. Dimola S, Caruso ML: Helicobacter pylori in animals affecting the human habitat through the food chain. Anticancer Res 1999, 19:3889-3894.
12. Contreras M, Morales A, Garcia-Amado MA, De Vera M, Bermudez V Gueneau P: Detection of Helicobacter-like DNA in the gastric mucosa of Thoroughbred horses. Lett Appl Microbiol 2007, 45:553-557.

13. Johnson B, Carlson GP, Vatistas NJ, Snyder JR, Lloyd K, Koobs J: Investigation of the number and location of gastric ulcerations in horses in race training submitted to the California Racehorse postmortem program. Proceedings of the 40th Annual Convention of the American Association of Equine Practitioners 1994, 123-124.

14. Amann RI, Ludwig W, Schleifer KH: Phylogenetic identification and in situ detection of individual microbial cells without cultivation. Microbiol Rev 1995, 59:143-169.

15. Recordati C, Gualdi V, Craveb M, Sala L, Luini M, Lanzoni A, Rishniw M, Simpson KW, Scanziani E: Spatial distribution of Helicobacter spp. in the gastrointestinal tract of dogs. Helicobacter 2009, 14:180-191.

16. Burton AB, Perkins GA, Parker J, Rosenthal R, Baumgart M, Simpson KW: The gastric mucosa of horses harbours an abundant and diverse bacterial flora [abstract]. Proceedings of American College of Veterinary Internal Medicine, Annual meeting, Seattle, WA, June 6-9 2007, 2007.

17. Niyogi SK: Shigellosis. Journal of Microbiology 2005, 43:133-143.

18. Farmer JJ, Fanning GR, Davis BR, Ohara CM, Riddle C, Hickmanbrenner FW, Asbury MA, Lowery VA, Brenner DJ: Escherichia-Fergusonii and Enterobacter-Taylorae, $2 \mathrm{New}$ Species of Enterobacteriaceae Isolated from Clinical Specimens. J Clin Microbiol 1985, 21:77-81.

19. Wragg P, La Ragione RM, Best A, Reichel R, Anjum MF, Mafura M, Woodward MJ: Characterisation of Escherichia fergusonii isolates from farm animals using an Escherichia coli virulence gene array and tissue culture adherence assays. Res Vet Sci 2009, 86:27-35.

20. Mahapatra A, Mahapatra S, Mahapatra A: Escherichia fergusonii: an emerging pathogen in South Orissa. Indian J Med Microbiol 2005, 23:204

21. Sarker SA, Gyr K: Non-immunological defence mechanisms of the gut. Gut 1992, 33:987-993.

22. Campbell-Thompson ML, Merritt AM: Gastric cannulation in the young horse: a new technique for studying gastric fluid secretion. Proceedings of the 2nd Annual Colic Research Symposium 1986, 120-122.

23. Dulphy JP, Martin-Rosset W, Dubroeuca H, Ballet JM, Detour A, Jailler M: Compared feeding patterns in ad libitum intake of dry forages by horses and sheep. Livestock Prod Sci 1997, 52:49-56.

24. Merritt AM, Sanchez LC, Burrow JA, Church M, Ludzia S: Effect of GastroGard and three compounded oral omeprazole preparations on 24 $\mathrm{h}$ intragastric $\mathrm{pH}$ in gastrically cannulated mature horses. Equine Vet $J$ 2003, 35:691-695.

25. Lowe SE, Pankratz HS, Zeikus JG: Influence of pH extremes on sporulation and ultrastructure of Sarcina ventriculi. J Bacteriol 1989, 171:3775-3781.

26. DeBey BM, Blanchard PC, Durfee PT: Abomasal bloat associated with Sarcina-like bacteria in goat kids. J Am Vet Med Assoc 1996, 209:1468-1469.

27. Vatn S, Tranulis MA, Hofshagen M: Sarcina -like bacteria, Clostridium fallax and Clostridium sordellii in Lambs with Abomasal Bloat, Haemorrhage and Ulcers. J Comp Pathol 2000, 122:193-200.

28. Vatn S, Gunnes G, Nybo K, Juul HM: Possible involvement of Sarcina ventriculi in canine and equine acute gastric dilatation. Acta Vet Scand 2000, 41:333-337.

29. Al Jassim RA, Scott PT, Trebbin AL, Trott D, Pollitt CC: The genetic diversity of lactic acid producing bacteria in the equine gastrointestinal tract. FEMS Microbiol Lett 2005, 248:75-81.

30. Varloud M, Fonty G, Roussel A, Guyonvarch A, Julliand V: Postprandial kinetics of some biotic and abiotic characteristics of the gastric ecosystem of horses fed a pelleted concentrate meal. J Anim Sci 2007, 85:2508-2516.

31. Yuki N, Shimazaki T, Kushiro A, Watanabe K, Uchida K, Yuyama T, Morotomi M: Colonization of the Stratified Squamous Epithelium of the Nonsecreting Area of Horse Stomach by Lactobacilli. Appl Environ Microbiol 2000, 66:5030-5034.

32. Scott DR, Marcus EA, Weeks DL, Lee A, Melchers K, Sachs G: Expression of the Helicobacter pylori urel gene is required for acidic $\mathrm{pH}$ activation of cytoplasmic urease. Infect Immun 2000, 68:470-477.

33. Wong WM, Wong BCY, Tang VSY, Lai KC, Yuen ST, Leung SY, Hu WH, Lam SK: An evaluation of the PyloriTek test for the diagnosis of Helicobacter pylori infection in Chinese patients before and after eradication therapy. J Gastroenterol Hepatol 2001, 16:976-980. 
34. Amann Rl, Binder BJ, Olson RJ, Chisholm SW, Devereux R, Stahl DA: Combination of $16 \mathrm{~S}$ Ribosomal-Rna-Targeted Oligonucleotide Probes with Flow-Cytometry for Analyzing Mixed Microbial-Populations. App/ Environ Microbiol 1990, 56:1919-1925.

35. Chan V, Crocetti G, Grehan M, Zhang L, Danon S, Lee A, Mitchell H: Visualization of Helicobacter species within the murine cecal mucosa using specific fluorescence in situ hybridization. Helicobacter 2005, 10:114-124.

36. Manz W, Amann R, Ludwig W, Wagner M, Schleifer KH: Phylogenetic Oligodeoxynucleotide Probes for the Major Subclasses of Proteobacteria Problems and Solutions. Syst Appl Microbiol 1992, 15:593-600.

37. Lane DJ: $16 \mathrm{~S} / 23 \mathrm{~S}$ rRNA sequencing. Nucleic acid techniques in bacterial systematics New York, N.Y: John Wiley \& Sons, IncStackebrandt E, Goodfellow M 1991, 115-147.

38. Leser TD, Amenuvor JZ, Jensen TK, Lindecrona RH, Boye M, Moller K: Culture-Independent Analysis of Gut Bacteria: the Pig Gastrointestinal Tract Microbiota Revisited. Appl Environ Microbiol 2002, 68:673-690.

doi:10.1186/1471-2180-10-84

Cite this article as: Husted et al:: Examination of equine glandular stomach lesions for bacteria, including Helicobacter spp by fluorescence in situ hybridisation. BMC Microbiology 2010 10:84.

\section{Submit your next manuscript to BioMed Central} and take full advantage of:

- Convenient online submission

- Thorough peer review

- No space constraints or color figure charges

- Immediate publication on acceptance

- Inclusion in PubMed, CAS, Scopus and Google Scholar

- Research which is freely available for redistribution

Submit your manuscript at www.biomedcentral.com/submit 